\title{
Preliminary evaluation of breeding perspectives of Ukrainian sweet cherry cultivars: nutraceutical properties and self-incompatibility
}

\author{
Szikriszt, B. ${ }^{1}$, Papp, N. ${ }^{2,3}$, Taller, D. ${ }^{1}$, Halász, J. ${ }^{1}$, Nyéki, J. ${ }^{3}$, Szabó, Z. ${ }^{3}$, Stefanovits-Bányai, É. ${ }^{2}$ \\ \& Hegedüs, A. ${ }^{1}$ \\ ${ }^{1}$ Corvinus University of Budapest, Faculty of Horticultural Science, Department of Genetics and Plant Breeding, \\ 1118 Budapest, Villányi út 29., Hungary; E-mail: hegedus.attila@uni-corvinus.hu \\ ${ }^{2}$ Corvinus University of Budapest, Faculty of Food Science, Department of Applied Chemistry, \\ 1118 Budapest, Villányi út 29., Hungary \\ ${ }^{3}$ University of Debrecen Centre for Agricultural and Applied Economic Sciences, \\ H-4032 Debrecen, Böszörményi út 138., Hungary
}

\begin{abstract}
Summary: Some traditional sweet cherry cultivars of Ukrainian origin may represent perspective material for Hungarian cherry breeding. A total of eight cultivars analysed represent great diversity in several phenotypic traits including fruit ripening time or fruit flesh colour. Considerable differences in the anthocyanin content may result in different antioxidant capacity of fruits. In the present study, we used ferric reducing antioxidant power (FRAP) and total phenolic content (TPC) assays to characterize fruits' nutraceutical properties. These values were compared with the respective values measured for eight commercial cultivars grown in Hungary. The average of FRAP and TPC values was higher for the Ukrainian cherries compared with commercial cultivars suggesting they might be included in functional breeding programs. Since, cherry is a self-incompatible species, the determination of $S$-genotype is required for both breeding and successful cultivar association in commercial orchards. Complete or partial $S$-genotypes were determined for 5 and 3 cultivars, respectively.
\end{abstract}

Keywords: antioxidant, cherry, Prunus avium, $S$-genotype, self-incompatibility, total phenolics

\section{Introduction}

Stone fruits consumption is expected to rise worldwide, since consumers pay more and more attention for their health. Therefore, natural foods having enhanced functional properties may be popular in the future. The increased consumption of fresh fruits has several health-promoting effects. Because of their high antioxidant capacity, fresh fruit reduce the risk of several degenerative diseases (i.a. cancer, stroke, cardiovascular diseases) (Liu, 2003; Scalzo et al., 2005; Dauchet \& Dallongeville, 2008).

Among stone fruits, sweet cherry (Prunus avium L.) is one of the most popular fruit containing considerable levels of ascorbic acid and polyphenolics (Serrano et al., 2005; Usenik et al., 2008). One of the most important polyphenolics in sweet cherry is anthocyanin. Fruits' anthocyanin content can be easily assessed from the red colour intensity of fruit peel and flesh. Some cultivars produce dark red or black fruits due to high contents of anthocyanins, while others contain only limited quantities from this compound. Comparing the antioxidant power of cultivars with differently coloured fruits may increase the popularity of formerly important traditional cultivars.
Most commercial sweet cherry cultivars are selfincompatible, which require another cultivar with different $S$ genotype for economically acceptable fruit set. Currently, 41 cross-incompatibility groups (CIG) are known (I-XLI) (Gisbert et al., 2008; Marchese et al., 2007; Schuster et al., 2007; Stanys et al., 2008; Tobutt et al. 2004). The members of such CIGs will not give eligible fruit set if interplanted in an orchard without another compatible cultivar. Different lengths of both introns in the $S$-RNase alleles have been successfully used to identify $S$-alleles in sweet cherry genotypes using polymerase chain reaction (PCR) (Sonneveld et al., 2001, 2003; Wiersma et al., 2001).

Sweet cherry displays great phenotypic and genetic diversity in Eastern Europe including Ukraine. Some cultivars were traditionally popular in the member states of the former Soviet Union ('Tavrichanka', 'Melitopolskaya' or 'Valeriy Chkalov' etc.) and hence were intensively used in breeding programs during the past decades. Since many fruit characteristics of these cultivars are still unknown (e.g. anthocyanin content, antioxidant properties), their inclusion into modern breeding programs may hold opportunities. In the present study we characterized some nutraceutical properties of eight Ukrainian cultivars and compared them to 
commercial cultivars. We have also determined their incompatibility genotypes to allow for designing successful parental combinations in breeding programs.

\section{Materials and methods}

\section{Cultivars tested}

Altogether, 16 sweet cherry cultivars and hybrids were used for the analyses: eight Ukrainian genotypes ('2115', 'Junskaya rannaya', 'Kodrinskaya', 'Kruplopodnaya', 'Kutuzovka', 'Melitopolskaya krapchataya', 'Perspektivnaya' and 'Podbelskaya') and eight commercial cultivars ('Alex', 'Ferrovia', 'Germersdorfi 3', 'Germersdorfi Rigl', 'Giant Red', 'Santina', 'Sunburst' and 'Sweet Heart'). All Ukrainian cherries were cultivated at the same germplasm collection of the Department of Genetics and Plant Breeding, CUB (Szigetcsép, Central Hungary), while commercial cultivars are kept in an orchard at Nagykutas, Hungary. Fruits and buds were collected during the season of 2009 .

\section{Fruit sample preparation}

For antioxidant assays, $100 \mathrm{~g}$ fruit were homogenized (peel and flesh together) and centrifuged with a Hettich Zentrifugen (Mikro 22 R; Tuttlingen, Germany) device (4 C, $35 \mathrm{~min}, 18750 \mathrm{~g}$ ), after which supernatants were used for most of the redox assays (exceptions are indicated). Samples for further analyses were kept at $-80^{\circ} \mathrm{C}$ until use.

\section{Antioxidant and total phenolic assays}

Antioxidant capacity was determined by the FRAP method (Benzie, \& Strain, 1996) and expressed as mmol ascorbic acid (AA)/L fruit juice or ìmol AA/100 g fresh weight. Total phenolic content (TPC) was measured using Folin-Ciocalteu's reagent according to the method of Singleton \& Rossi (1965). The content of soluble phenols was calculated from a standard curve based on gallic acid concentration.

\section{DNA extraction and PCR analyses}

Genomic DNA was extracted from buds using the DNeasy Plant Mini Kit (Qiagen, Hilden, Germany). PCR was conducted using cherry consensus primer pairs of PaConsI-F [5' -(C/A)CT TGT TCT TG(C/G) TTT (T/C)GC TTT CTT C-3'], PaConsI-R [5'-CAT G(A/G)A TGG TGA A(A/G)T (T/A)TT GTA ATG G-3'] amplifying the first intron; and PaConsII-F [5'-G GCC AAG TAA TTA TTC AAA CC-3'], PaConsII-R [5'-CA(T/A) AAC AAA (A/G)TA CCA CTT CAT GTA AC-3'] for amplification of the second intron (Sonneveld et al., 2003). Approximately 20-80 ng of genomic DNA was used for PCR amplification in a $25 \mu \mathrm{l}$ reaction volume, containing $1 \times \mathrm{PCR}$ buffer (Sigma, Budapest, Hungary) with final concentrations of $10 \mathrm{mM}$
Tris- $\mathrm{HCl}$ (pH 8.3), $50 \mathrm{mM} \mathrm{KCl,} 1.5 \mathrm{mM} \mathrm{MgCl} 2,0.2 \mathrm{mM}$ of dNTPs, $0.4 \mu \mathrm{M}$ of the adequate primers and $0.625 \mathrm{U}$ of Taq DNA polymerase (Sigma, Budapest, Hungary). PCR was carried out in a PTC 200 thermocycler (MJ Research) according to Sonneveld et al. (2003). PCR products were separated by electrophoresis in 2\% TAE agarose gels for $2 \mathrm{~h}$ at $100 \mathrm{~V}$ and DNA bands were visualized by ethidium bromide staining. Fragment lengths of the second intron PCR were estimated by comparison with the $1 \mathrm{~kb}+$ DNA ladder (Promega, Madison, Wisconsin, USA). To determine the exact size of the $S$-RNase first intron region fragments under $600 \mathrm{bp}$, the fluorescently labelled products were run in an automated sequencer ABI PRISM 3100 Genetic Analyzer (Applied Biosystems, Budapest, Hungary).

\section{Statistical analysis}

Correlation analyses of redox parameters and one-way analysis of variance (ANOVA) were carried out in Microsoft Excel 2003. Significant differences were calculated according to Duncan's multiple range tests. Differences at $P 0.05$ were considered statistically significant.

\section{Results and discussion}

Ferric reducing antioxidant power (FRAP) is a widely used assay to characterize antioxidant activity of a wide range of fruits (Hegedüs et al., 2008; 2010; Papp et al., 2010; Yilmaz et al., 2009). For this reason, we have measured the FRAP value in fruit extracts of Ukrainian sweet cherries and found that FRAP ranged between 1.00 and 6.80 mmolAA/L (Figure 1A). The smallest value was determined in 'Junskaya rannaya', an early ripening cultivar with light red coloured fruits. Similarly to other fruits, early ripening time might be associated with restricted antioxidant capacity of fruits (Hegedüs et al., 2010; Leccese et al., 2008). The highest FRAP value was measured in fruits of 'Kutuzovka', a black coloured cultivar. The average value of the eight tested cultivars was 4.07 mmolAA/L compared with 2.21 mmolAA/L obtained for the commercial cultivars. For the eight commercial cultivars, FRAP values ranged from 1.32 ('Sweet Heart') to 4.55 ('Santina') (Figure 1B). While antioxidant capacity was under $3 \mathrm{mmolAA} / \mathrm{L}$ for seven of the eight commercial cultivars, six of the Ukrainian cultivars had higher FRAP value than 3 mmolAA/L. It confirms that Ukrainian sweet cherries might be rich sources of antioxidants compared with the most popular commercial cherries.

The total phenolic content in fruits of the Ukrainian cultivars ranged between 4.02 and $8.14 \mathrm{mgGA} / \mathrm{ml}$ (Figure $2 A$ ). Similarly to the FRAP results, 'Junskaya rannaya' had the lowest and 'Kutuzovka' had the highest total phenolic contents. It confirms that sweet cherry antioxidant capacity is primarily associated with phenolic compounds including anthocyanins. For commercial cultivars, the lowest (2.49 $\mathrm{mgGA} / \mathrm{ml})$ and highest (6.87 $\mathrm{mgGA} / \mathrm{ml})$ TPC values were 

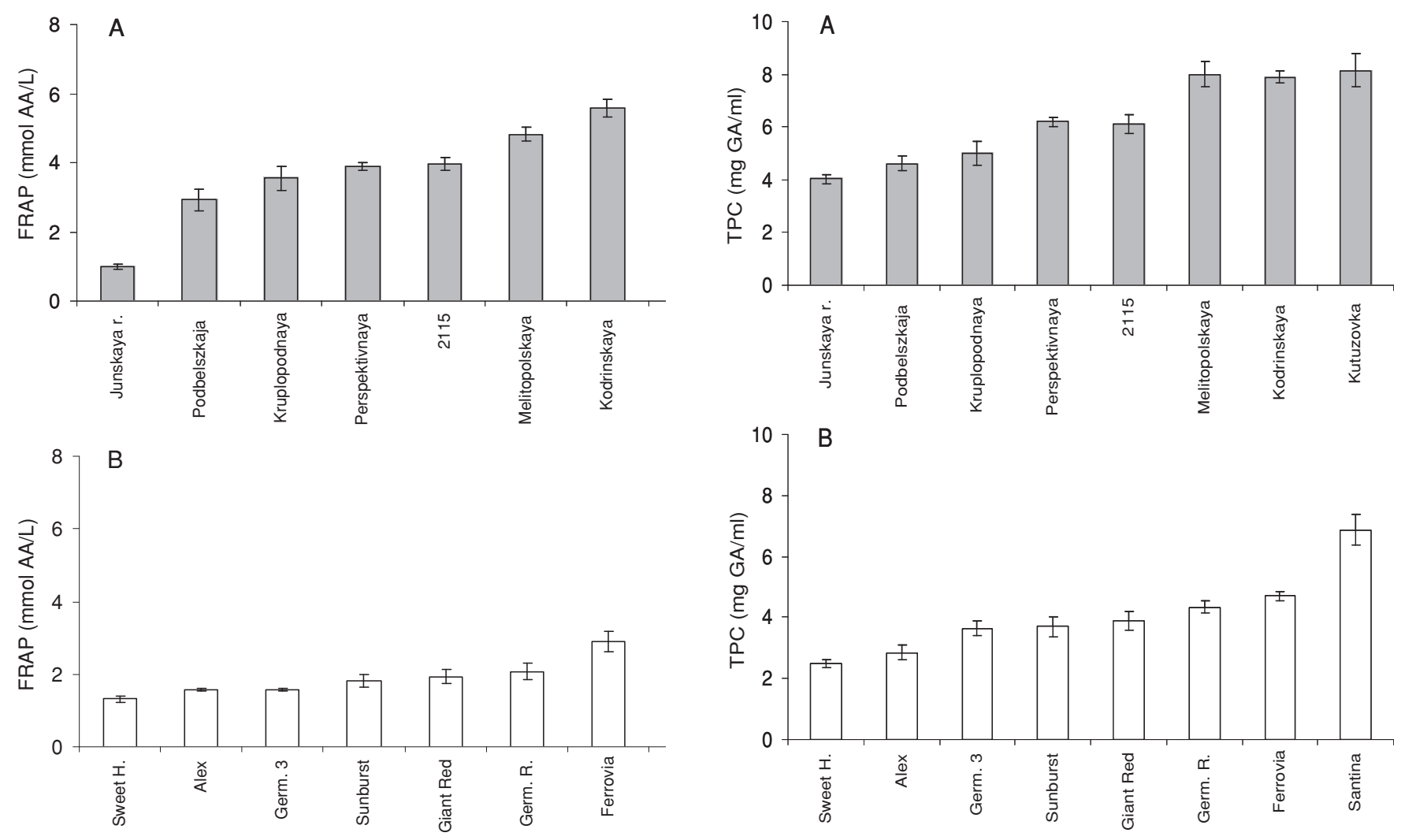

Figure 1: Antioxidant capacity of Ukrainian (A) and commercial (B) sweet cherry cultivars in 2009, Szigetcsép, Hungary

also determined for the cultivars with the lowest and highest antioxidant capacity, respectively (Figure $2 B$ ). The average TPC value of Ukrainian cultivars was $6.24 \mathrm{mgGA} / \mathrm{ml}$, which exceeded the average value of $4.06 \mathrm{mgGA} / \mathrm{ml}$ for commercial cultivars. Sweet cherry was shown to accumulate great levels from coloured and colourless polyphenolics (Serrano et al., 2005; Usenik et al., 2008). In addition to their antioxidant power, the favourable healtheffects of flavonoids including antiproliferative effect, inhibitory action on inflammatory cells are well known (Kim et al., 2005; Middletown et al., 2000). The areas that hold most promise to use flavonoids as curative agents are chronic inflammatory and allergic diseases, as well as coronary artery disease and breast cancer.

The interdependence between FRAP and TPC values was close with $r=0.92$ and $r=0.86$ for Ukrainian and commercial cultivars, respectively. The close relationship between the two parameters further confirms that phenolic compounds are crucial in shaping the antioxidant value of sweet cherry fruit. We found that cultivars with darker fruit colour possessed higher antioxidant capacity and phenolic content.

Since most Ukrainian cultivars were confirmed to accumulate higher levels of antioxidant capacity and polyphenolics content, their future inclusion in breeding programs might be reasonable. However, sweet cherry is a self-incompatible species (Boskovic \& Tobutt, 1996; Crane, 1925). and hence for breeding and cultivation, the $S$ genotype of the new cultivar candidates must be determined to avoid unsuccessful crossing combinations in breeding and

Figure 2: Total phenolics content of Ukrainian (A) and commercial (B) sweet cherry cultivars in 2009, Szigetcsép, Hungary

ineligible fruit set in commercial orchards. Therefore, we used PCR analysis to determine the $S$-genotype and mutual compatibility properties of Ukrainian cherries.

The PCR strategy for cherry $S$-genotyping was elaborated by Sonneveld et al. (2001; 2003). This approach uses a combination of primer pairs designed from conserved regions of the Prunus S-RNase gene. Two pairs of primers are used for the amplification of the first and second intron regions of the gene. The size of introns changes in an allelespecific manner. In our analysis, we detected five different fragment lengths both for first and second intron analysis (Fig. 3, Table 1). The combination of the fragment lengths was used to identify the following alleles in Ukrainian cherries: $S_{3}, S_{4}, S_{5}, S_{6}$ and $S_{9}$. For three cultivars, 'Kutuzovka', 'Perspektivnaya' and 'Podbelskaya'; only partial $S$-genotype was determined presumably due to preferential amplification.

Four of the five complete genotypes were identical with those of the V, VII and X cross-incompatibility groups (Table 1). It indicates that 'Junskaya rannaya' and 'Kodrinskaya' should not be associated in the same orchard without pollenizer cultivars. In addition, these cultivars if interplanted with others in CIG V including 'Carmen' or 'Turkey Heart' will require pollenizers for reliable fruit set. Similarly, 'Melitopolskaya krapchataya' will not be fertilized by 'Tünde' or other cultivars from CIG VII and the hybrid 2115 is incompatible with 'Bigarreau de Jaboulay' and others in CIG X. The cultivar 'Kruplopodnaya' (it has been recently recognized in Hungary) had the $S_{5} S_{9}$ incompatibility 
Table 1: Fragment lengths of first and second intron regions, S-genotype and respective cross-incompatibility groups of Ukrainian sweet cherry cultivars

\begin{tabular}{|c|c|c|c|c|}
\hline Cultivars & $\begin{array}{l}\text { Fragment length of first } \\
\text { intron PCR product }{ }^{1}\end{array}$ & $\begin{array}{l}\text { Approximate fragment length } \\
\text { of second intron PCR product }\end{array}$ & S-genotype & $\begin{array}{l}\text { Cross-incompatibility } \\
\text { groups }\end{array}$ \\
\hline Junskaya rannaya & 462,523 & 1050,2200 & S4S5 & $\mathrm{V}$ \\
\hline Kodrinskaya & 462,523 & 1050,2200 & S4S5 & V \\
\hline Kruplopodnaya & 428,462 & 800,2200 & S5S9 & XXXVII \\
\hline Kutuzovka & 303 & 900 & S3 & - \\
\hline Melitopolskaya krapchataya & 303,462 & 900,2200 & S3S5 & VII \\
\hline Perspektivnaya & - & 800 & S9?3 & - \\
\hline Podbelskaya & 303 & 900 & S3 & - \\
\hline 2115 & 428,518 & 600,800 & S6S9 & $X$ \\
\hline
\end{tabular}

${ }^{1}$ Sized on automated sequencer

${ }^{2}$ Sized on agarose gels by comparing with $1 \mathrm{~kb}+$ size marker

${ }^{3}$ It must be confirmed by allele-specific PCR

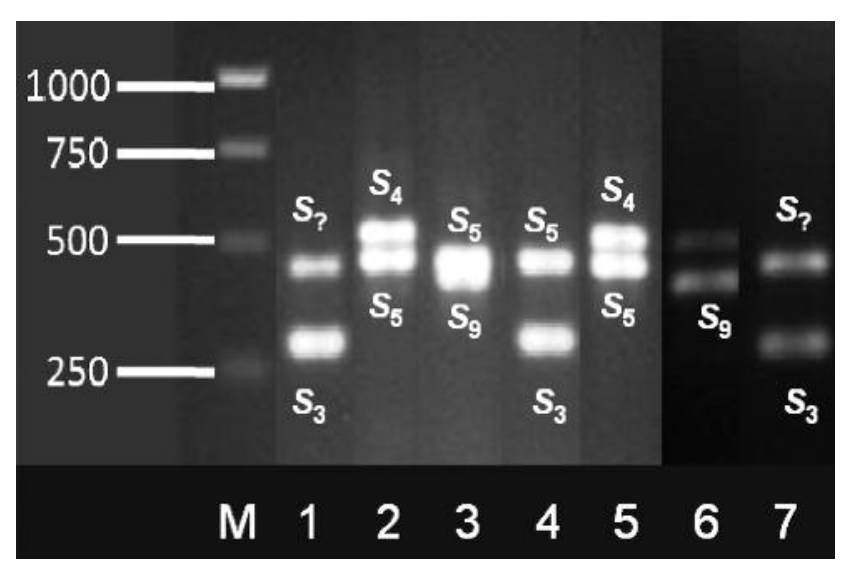

Figure 3: PCR analysis of Ukrainian sweet cherry cultivars with the PaConsI-F and -R primers amplifying the first intron region of the Prunus S-RNase gene. M: 1kb+ DNS marker, 1. 'Podbelskaya', 2. 'Kodrinskaya', 3. 'Krupnoplodnaya', 4. 'Melitopolskaya', 5. 'Junskaya rannaya', 6. 2115, 7. 'Kutuzovka'. The PCR of 'Perszpektivnaya' failed

genotype (similar to the results of Schuster et al., 2007), which was also assigned to the Sicilian cultivar 'Cavallaro' (Marchese et al., 2007). However, since this is not cultivated in Hungary, 'Kruplopodnaya' seems to be appropriate for using as a universal pollen donor for any commercial cultivars currently grown in Hungary.

Our results lead us to the conclusion that Ukrainian sweet cherries might be perspective in future breeding programs since their fruit accumulate higher antioxidant contents than popular and widely grown commercial cultivars. This study also provides information on their $S$-genotypes, which will be useful in designing parental combinations and determining the allelic composition of offspring.

\section{Acknowledgements}

This work was co-financed by the OTKA K84290, NKTH-OTKA K68921 and TÁMOP 4.2.1./B-09/01-KMR2010-0005 grants. Júlia Halász and Attila Hegedűs are grateful for receiving a János Bolyai Scholarship, Hungarian Academy of Sciences and Éva Stefanovits-Bányai for the award Excellence in Science, Corvinus University of Budapest.

\section{References}

Bekefi, Zs., Tobutt, K.R. \& Sonneveld, T. (2003): Determination of (in)compatibility genotypes of Hungarian sweet cherry (Prunus avium L.) accessions by PCR based methods. Int. J. Hortic. Sci., 9: 37-42.

Benzie, I.I.F. \& Strain, J.J. (1996): The ferric reducing ability of plasma (FRAP) as a measuring of "antioxidant power": The FRAP assay. Ann. Biochem., 239: 70-76.

Bokovi, R. \& Tobutt, K.R. (1996): Correlation of stylar ribonuclease zymograms with incompatibility alleles in sweet cherry. Euphytica, 90: 245-250.

Crane, M.B. (1925): Self-sterility and cross-incompatibility in plums and cherries. J. Genet., 15: 301-322.

Dauchet, L. \& Dallongeville, J. (2008): Fruit and vegetables and cardiovascular disease: epidemiological evidence from the nonWestern world. Brit. J. Nutr., 99: 219-220.

Gisbert, A.D., Badenes, M.L., Tobutt, K.R., Llacer, G. \& Romero, C. (2008): Determination of the $S$-allele composition of sweet cherry (Prunus avium L.) cultivars grown in the southeast of Spain by PCR analysis. J. Hortic. Sci. Biotechnol., 83: 246-252.

Hegedüs, A., Balogh, E., Engel, R., Sipos, B.Z., Papp, J., Blázovics, A. \& Stefanovits-Bányai, É. (2008): Comparative nutrient element and antioxidant characterization of berry fruit species and cultivars grown in Hungary. HortScience, 43: 1711-1715.

Hegedüs, A., Engel, R., Abrankó, L., Balogh, E., Blázovics, A., Hermán, R., Halász, J., Ercisli, S., Pedryc, A. \& StefanovitsBányai, É. (2010): Antioxidant and antiradical capacities in apricot (Prunus armeniaca L.) fruits: variations from genotypes, years and analytical methods. J. Food Sci., 75(9): C722-C730.

Kim, D.-O., Heo, H.J., Kim, Y.J., Yang, H.S. \& Lee, C.Y. (2005): Sweet and sour cherry phenolics and their protective effects on neuronal cells. J. Agric. Food Chem., 53: 9921-9927. 
Leccese, A., Bartolini, S. \& Viti, R. (2008): Total antioxidant capacity and phenolics content in fresh apricots. Acta Aliment. Hung., 37: 65-76.

Liu, R.H. (2003): Health benefits of fruit and vegetables are from additive and synergistic combinations of phytochemicals. Amer. J. Clin. Nutr., 78: 517S-520S.

Marchese A, Tobutt KR, Raimondo A, Motisi A, Bokovi, R., Clarke, J. \& Caruso, T. (2007): Morphological characteristics, microsatellite fingerprinting and determination of incompatibility genotypes of Sicilian sweet cherry cultivars. J. Hortic. Sci. Biotechnol., 82: 41-48.

Middleton, E.J., Kandaswami, C. \& Theoharides, T.C. (2000): The effects of plant flavonoids on mammalian cells: Implications for inflammation, heart disease, and cancer. Pharmacol. Rev., 52: 673-751.

Papp, N., Szilvássy, B., Abrankó, L., Szabó, T., Pfeiffer, P., Szabó, Z., Nyéki, J., Ercisli, S., Stefanovits-Bányai, É. \& Hegedús, A. (2010): Main quality attributes and antioxidants in Hungarian sour cherries: identification of genotypes with enhanced functional properties. Int. J. Food Sci. Tech., 45: 395-402.

Scalzo, J., Politi, A., Pellegrini, N., Mezzetti, B. \& Battino, M. (2005): Plant genotype affects total antioxidant capacity and phenolic contents in fruit. Nutrition, 21: 207-213.

Schuster, M., Flachowsky, H. \& Kohler, D. (2007): Determination of self-incompatible genotypes in sweet cherry (Prunus avium L.) accessions and cultivars of the German Fruit Gene Bank and from private collections. Plant Breeding, 126: 533-540.

Serrano, M., Guillén, F., Martínez-Romero, D., Castillo, S. \& Valero, D. (2005): Chemical constituents and antioxidant activity of sweet cherry at different ripening stages. J. Agric. Food Chem., 53: 2741-2745.
Singleton, V.L. \& Rossi, J.A. (1965): Colorimetry of total phenolics with phosphomolybdic phosphotungstic acid „reagents”. Am. J. Enol. Vitic., 16: 144-158.

Sonneveld, T., Tobutt, K.R. \& Robbins, T.P. (2003): Allelespecific PCR detection of sweet cherry self-incompatibility $(S)$ alleles $S 1$ to $S 16$ using consensus and allele-specific primers. Theor. Appl. Genet., 107: 1059-1070.

Sonneveld, T., Robbins, T.P., Bokovi, R. \& Tobutt, K.R. (2001): Cloning of six cherry sweet self-incompatibility alleles and development of allele-specific PCR detection. Theor. Appl. Genet., 102: 1046-1055.

Stanys, V., Stanyte, R., Staniene, G. \& Vinskiene, J. (2008): $S$ allele identification by PCR analysis in Lithuanian sweet cherries. Biologija, 54: 22-26.

Tobutt, K.R., Sonneveld, T., Bekefi, Z. \& Bošković, R. (2005): Cherry (in)compatibility genotypes - an updated cultivar table. Acta Hort., 663: 667-671.

Usenik, V., Fabcic, J. \& Stampar, F. (2008): Sugars, organic acids, phenolic composition and antioxidant activity of sweet cherry (Prunus avium L.). Food Chem., 107: 185-192.

Wiersma, P.A., Wu, Z., Zhou, L., Hampson, C. \& Kappel, F. (2001): Identification of new self-incompatibility alleles in sweet cherry (Prunus avium L.) and clarification of incompatibility groups by PCR and sequencing analysis. Theor. Appl. Genet., 102: 700-708.

Yilmaz, K.U., Ercisli, S., Zengin, Y., Sengul, M. \& Kafkas, E.Y. (2009): Preliminary characterization of cornelian cherry (Cornus mas L.) genotypes for their physico-chemical properties. Food Chem., 114: 408-412. 